\title{
WILLINGNESS TO COMMUNICATE IN FOREIGN LANGUAGE ACQUISITION
}

\author{
Elis Susanti \\ (weasley.ndha@yahoo.com) \\ Pendidikan Bahasa Inggris \\ Universitas Muhammadiyah Kotabumi
}

\begin{abstract}
Abstrak
Karena tujuan utama pembelajaran bahasa asing adalah agar siswa mampu menggunakannya untuk berkomunikasi, penting untuk mengetahui alasan-alasan yang membuat siswa enggan menggunakan bahasa asing yang dipelajari untuk berkomunikasi. Salah satu faktor internal yang diasumsikan oleh banyak peneliti menjadi penyebab utama yang menentukan penggunaan bahasa asing yang dipelajari dalam komunikasi yakni Willingness to Communicate (WTC). WTC merupakan kecenderungan siswa untuk terlibat atau tidak dalam suatu komunikasi menggunakan bahasa asing yang dipelajari. Semakin tinggi tingkatan WTC seseorang, semakin sering ia akan terlibat dalam komunikasi menggunakan bahasa asing yang dipelajari sehingga pada akhirnya akan membuat kemampuan berbahasa asingnya meningkat dikarenakan frekuensi penggunaan atau implementasi yang lebih sering. Tingkatan WTC dipengaruhi oleh banyak faktor diantaranya self-esteem, motivasi, anxiety, dan faktor-faktor individual lainnya. Oleh karenanya, guru bahasa Inggris sebaiknya mengimplementasikan strategistrategi pembelajaran yang mampu meningkatkan WTC siswa sehingga siswa akan lebih sering menggunakan bahasa asing yang dipelajari untuk berkomunikasi.
\end{abstract}

\section{INTRODUCTION}

Nowadays, the focus of EFL teaching is on its communication purpose which means that the targeted goal is to enable the EFL language learners to communicate using the language in a meaningfull and effective communication (Clement et al., 2003). Due to the fact, the teaching of speaking provides such a very challenging point for EFL teachers whenever the EFL teachers are demanded to encourage their students to participate or involve in various speaking activities in the classroom with the fact that speaking itself is such a complex skill in which its acquisition is not easy for the language learners. In order to improve communicative skill, language learners need to use the language (Yashima, Zenuk-Nishide, \& Shimizu, 2004) meaning that they have to do more practice to expose the language. However, since English is only as a foreign language so that students only have little exposure for their English. Students do not have supplementary time to use the language outside the classroom. This condition is such problematical issue faced by all EFL teachers which need to get more attention. 
The successfull of FL acquisition is determined by various factors which three of all are contextual (the status of the foreign language learned, availability of resources, etc.,), situational (the level of formality needed in an interaction, et.,), and individual factors (motivation, self-esteem, language anxiety, etc.,) (Dewaele, Comanaru, and Faraco, 2013). One of the individual factors which needs to take into consideration is about the students' readiness to get involve in a communication using the language learned. Whenever the students feel ready to take part, they will take part in a particular communication freely and fluently. Otherwise, when they decided to keep silent (do not engage in the communication), it means that they do not have any psychologically preparedness for that.

This such readiness is termed as a willingness feeling to communicate using the language learned (WTC). WTC is an important variable that should be taken into account in teaching speaking as a foreign language. Clement et al., (2003) in his research identified that WTC is such a model containing the integration of psychological, linguistic, and communicative variables which will determine the L2 communication achievement. Clement, Dornyei, and Noels in Zade and Hashemi (2014:290) state that the function of WTC could be as an individual difference variable in L2 learning as well as a targeted goal of L2 instruction. In this case, WTC is seen as a variable which entails in a personality trait of an individual in which it is different from one individual and others, and the main purpose of a L2 or EFL instruction is at the end to make the language learners willing to take part or get involve in a communication.

Furthermore, it is stated by Manipuspika (2018:201) that a high willingness to use the foreign language learned will reveal an authentic communication inside the classroom. It is clear that WTC is such individual variable which help the language learners acquire better skill in using the language learned to communicate. The lack of WTC affects students' activeness in communication (Gharibi \& Seyyedrezaei, 2016:194). Chan and McCroskey in Zhade and Hasemi (2014:291) and Gharibi and Seyyedrezaei (2016: 195) claimmed that the higher students' WTC is the more oral production resulted by the students, and vise versa which lead to the students' success in learning the language. It is assumed that high WTC is associated with the increase of students' frequency in using the language which lead to their success in learning that language (Gharibi and Seyyedrezaei, 2016: 195). Additionally, Yashima, ZenukNishide and Shimizu (2004) also state that 
"students who show willingness to communicate in various contact situations are more inclined to initiate communication in the classroom". Due to the facts, it is clear that WTC is an important variable which should get more attention from the EFL teachers in teaching speaking. English teachers should understand well how to make their students willing to engage in a communication using the language learned. It is also essential that English teachers understand what factors which might be able to affect students' WTC to be high or low.

With regard to the importance of WTC toward the teaching of speaking, this article will discuss and elaborate about the essential of WTC toward the teaching of speaking, more variables which determine students' WTC, and several previous related research results which describe how WTC might be a crucial aspect in a speaking class. It is hoped that having known the information, English teachers would be more preparable in teaching speaking by applying appropriate teaching strategy which could enhance the students' WTC during and after the language classroom activities.

\section{DISCUSSION}

Willingness to Communicate and Its Related Variables
To get involved in a spoken communication, someone should be ready for several aspects like psychologically ready to speak up without feeling shy, nervous, lack confidence, and so forth. This psychologically readiness which makes someone involve in a communication using the language learned is represented by WTC (MacIntyre, 2007). Meanwhile, McCroskey and Baer in Manipuspika (2018: 204) define WTC as "a stable predisposition toward communication when free to choose to do so". They point out that students who are willing to communicate are those who do not have any obstacle in speaking. Additionally, According to Baker \& MacIntyre (2000), WTC refers to a student's predisposition towards or away from communicating. The more willing the student is, the more benefit that would be obtained by students for their communicative activities (Ellis, 2004). It is because the frequency of their L2 use raises (MacIntyre, Baker, Clément, \& Conrod, 2001) so that they have more chance to practice and expose their L2 which also increases their activeness and independence (S.-J. Kang, 2005). As the result, MacIntyre et al., (2001) \& MacIntyre et al., (1998) assume that they would achieve a better language competence.

WTC has been so long associated with many individual variables such as motivation, anxiety, attitude, interpersonal 
attraction, etc., (MacIntyre, 2007). Additionally, McIntyre (2007) also states that social contextual variables like ethno linguistic vitality, language contact, etc., also the variables which could affect one's WTC. Meanwhile, McCroskey in Manipuspika (2018) points out several variables that determine the level of WTC, they are: introversion, self-esteem, communication competence, cultural diversity, and communication apprehension. Both McIntyre and McKroskey seem to have the same idea that WTC is greatly influenced by either individual or social variables.

Further, MacIntyre, Clément, Dörnyei and Noels in Dewaele, Comanaru, and Faraco (2013) proposed a more complex theoretical model for L2 WTC in the model of pyramid. In this pyramid model, WTC is on the top position as a variable which affects to the L2 use. The first three layers on the top of the pyramid are the variables which will determine one's WTC at the first time somebody wants to choose whether to engage or to keep silent whenever an opportunity to communicate using the L2 comes. Those are communication behavior (L2 use), behavioral intention (WTC), and situated antecedent (desire to communicate with a specific person and state communicative self-confidence). Meanwhile, the next three layers describe some variables (motivational prospensities, affective-cognitive context, and social and individual context) which will affect to the WTC's endurence during the communication.

\section{Previous Studies}

More previous studies which probed the effect of individual variables toward students' WTC have been conducted by many researchers. First, a study about the importance of self-confidence also have been conducted and revealed selfconfidence plays important role for determining one's WTC. Ghanbarpour (2016) investigated the effect of selfconfidence on the students' WTC. The result found that students' self-confidence gives significant effect on students' WTC in an EFL instruction.

Further, self-confidence is also associated with one's motivation in which motivation could enhance one's WTC in L2 use. Hashimoto (2002) pointed out motivation as one of the main factors which gives significant effect on students' eagerness in communicating using English. His study also resulted a fact that motivation has a direct relationship with students' WTC. Motivated students will be more inclined to be brave in taking part in a communication rather than the unmotivated student. Thus, motivation is also a variable that should be taken into account when EFL 
teachers want to raise their students' WTC in a speaking class.

Apart from motivation issue in determining one's WTC, self-esteem which is about one's evaluation about himself is an individual variable which could determine one's WTC. It is known when somebody gives high worth on himself, he believes he is able to do what others can do. This such mindset could increase his confidence which then take him to be brave and ready to take part willingly in a communication. It is stated by McCroskey and Richmond in Ghanbarpour (2016) that low self-esteem causes lack willingness to communicate. The importance of selfesteem and WTC toward students' performance in spoken language has been probed in a study conducted by Zade and Hashemi (2014) which is found that both self-esteem and WTC altogether help the language learners fluently in delivering a lecture using spoken language in front of the class. This research broke a theory from Bachman and Palmer (1996) and Çetinkaya (2007), which pointed out self-esteem as the first and main factor in speaking performance. In fact, throughout their research, Zade and Hashemi found that both self-esteem and WTC play important role for students' speaking performance.

Additionally, another previous study conducted by Manipuspika (2018) investigated about the relationship between anxiety and WTC which reveals that there is significant correlation between anxiety and WTC. This study found that students with high level WTC tend to have low desire to speak using the language learned. Meanwhile, Rastegar \& Karami (2015) which investigated the relationships among foreign language classroom anxiety, willingness to communicate, and the scholastic success of Iranian EFL learners found that anxiety and WTC is negatively correlated, while WTC and scholastic success has positive correlation.

Another research conducted by Thousi and Khalaji (2014) has investigated the impact on WTC on students' speaking ability. It is found that WTC correlates significantly with students' speaking ability. MacIntyre \& Charos, 1996; MacIntyre \& Clément, 1996) in their study found that "WTC greatly influenced the frequency of communication in L2, and was in turn influenced by perceived competence in L2, motivation to engage in an exchange in L2, and to a lesser extent, anxiety to communicate in L2".

\section{CONCLUSION \& SUGGESTION}

\section{Conclusion}

The acquisition of EFL is affected by many variables. Three of the variables are: (1) Individual variables sucha as WTC, self-esteem, motivation, self-confidence, anxiety, etc., (2) social contextual variables 
like language contact, cultural diversity, ethno linguistics vitality, etc., (3) situational variables. WTC which belongs to individual variables has been investigated by many researchers to have significant correlation with students' predisposition to engage in a communication. In a further study which reveals a pyramidal model of WTC theory, WTC is on the first top position to be the variable which affects one's L2 use. Furthermore, in many previous studies, it is assumed that the higher WTC is, the more frequency of the L2 use will be which leads to the better improvement of students' speaking performance. Moreover, several previous studies have been conducted and revealed that WTC is influenced by various variables such as self-esteem, motivation, selfconfidence, anxiety, and so forth. These variables will determine the level of students' WTC in using the language learned.

\section{Suggestion}

Refering to the conclusion, several suggestions are put forwards as follows:
- EFL teachers is suggested to set a speaking classroom activity which can enhance students' WTC. The speaking activity could present the activities with interesting and familiar topics which will stimulate the students to take part in those speaking activities.

- It is also essential that EFL teachers apply a strategy which can enhance students' self-esteem, motivation, and other individual factors which affect students' WTC.

- Because WTC is also influenced by communicative competence which belongs to situational variables, it is also essential that EFL teachers find an effective strategy to improve students' communicative competence which relates to several aspects like pronunciation, vocabulary, grammar, and so on. An effective strategy applied is hoped to help the students raise their communicative competence so that whenever they have sufficient communicative competence, they will be more confident to initiate or take part in a communication using the language learned.

\section{REFERENCES}

Alqahtani, Majed. 2015. Saudi Students' Willingness to Communicate and Success in Learning English as a Foreign Language. Journal of Language Teaching and Research, Vol. 6 (6), 1195-1205. 
Bachman, L. F. \& Palmer, A. S. 1996. Language testing in practice. Oxford: Oxford University Press.

Baker, S. C., \& MacIntyre, P. D. 2000. The role of gender and immersion in communication and second language orientations. Language Learning, Vol. 50, 311-341.

Clément, R., Baker, S. C., \& MacIntyre, P. D. 2003. Willingness to communicate in a second language: The effects of context, norms, and vitality. Journal of Language and Social Psychology, Vol. 22(2), 190-209.

Çetinkaya B, Y. 2007. Turkish students' willingness to communicate in English. Dokuz Eylül Üniversiy, Buca.

Dewaele, Jean-Marc., Comanaru, Ruxandra-S., \& Faraco, Martine. 2013. The affective benefits of a pre-sessional course at the start of study abroad. Social interaction, identity and language learning during residence abroad, 95-114.

Ellis, R. (2004). Individual differences in second language learning. In A. Davies \& C. Elder (Eds.), The handbook of applied linguistics (pp. 525-551). Malden, ma: Blackwell.

Gharibi, Saeid., \& Seyyedrezaei, Seyyed Hassan. 2016. The Importance of Willingness to Communicate and Self-Esteem in Language Learning and Teaching. JIEB, Vol. 4, 194-197.

Hashimoto, Y. 2002. Motivation and willingness to communicate as predictors of reported L2 use: The Japanese ESL context. Second Language Studies, Vol.20 (2), 29-70.

Kang, S.-J. (2005). Dynamic emergence of situational willingness to communicate in a second language. System, Vol. 33(2), 277-292.

Manipuspika, Yana Shanti. 2018. Correlation between Anxiety and Willingness to Communicate in the Indonesian EFL Context. Arab World English Journal (AWEJ) Vol. 9 (2), 200-217.

MacIntyre, P. D., Dornyei, Z., Clément, R., \& Noels, K. A. 1998. Conceptualizing willingness to communicate in a 12: A situational model of 12 confidence and affiliation. The Modern Language Journal, Vol. 82(4), 545-562.

MacIntyre, P. D., Baker, S. C., Clément, R., \& Conrod, S. 2001. Willingness to communicate, social support, and language-learning orientations of immersion students. Studies on Second Language Acquisition, Vol.23(3), 369-388.

MacIntyre, P.D. 2007. Willingness to communicate in the second language: Understanding the decision to speak as a volitional process. Modern Language Journal, Vol. 91, 564576.

Rastegar, M. \& Karami, M. 2015. On the Relationship between Foreign Language Classroom Anxiety, Willingness to Communicate and Scholastic Success among Iranian EFL Learners. Theory and Practice in Language Studies, Vol. 5(11), 2387-2394.

Tousi, Seyyed Mohsen., \& Khalaji, Hamidreza. 2014. The Impact of Willingness to Communicate on Iranian EFL Learners Speaking Ability. International Research Journal of Applied and Basic Sciences, Vol, 8 (11), 1866-1869. 
Yashima, T., Zenuk-Nishide, L., \& Shimizu, K. (2004). Influence of attitudes and effect on L2 communication: A study of Japanese high school students. Language Learning, Vol.54(1), 119-152.

Zade, Mohadese Habib., \& Hashemi, Akram. 2014. Self-esteem, willingness to communicate, and oral production: The case study of Iranian intermediate EFL students. International Journal of Language and Linguistics, Vol. 2(4): 290-294. 